\title{
Infuence of Metabolic Syndrome on Hearing Outcome in Sudden Sensorineural Hearing Loss
}

\author{
Jong Joong Choi ${ }^{1}$, Myeong Hee Kim ${ }^{1}$, Jong Won Lee ${ }^{1}$, Do Young Jung ${ }^{1}$, and Jong Bin Lee ${ }^{1,2}$ \\ ${ }^{1}$ Department of Otorhinolaryngology-Head and Neck Surgery, Konyang University College of Medicine, Daejeon; and \\ ${ }^{2}$ Konyang University Myunggok Medical Research Institute, Daejeon, Korea
}

\section{대사증후군이 돌발성 난청의 청력 결과에 미치는 영향}

\author{
최종중 ${ }^{1} \cdot$ 김명희 $^{1} \cdot$ 이종원 $^{1} \cdot$ 정도영 $^{1} \cdot$ 이종빈 $^{1,2}$ \\ 건양대학교 의과대학 이비인후-두경부외과학교실, ${ }^{1}$ 건양대학교 명곡의과학연구소 ${ }^{2}$
}

\author{
Received October 20, 2017 \\ Revised November 17, 2017 \\ Accepted November 28, 2017 \\ Address for correspondence \\ Jong Bin Lee, MD, PhD \\ Department of Otorhinolaryngology- \\ Head and Neck Surgery, \\ Konyang University \\ College of Medicine, \\ 158 Gwanjeodong-ro, Seo-gu, \\ Daejeon 35365, Korea \\ Tel $+82-42-600-8840$ \\ Fax $+82-42-543-8959$ \\ E-mailrogue25@chol.com
}

Background and Objectives Sudden sensorineural hearing loss (S-SNHL) has been reported to be associated with hypertension, diabetes mellitus, hyperlipidemia, and stroke in previous studies. The purpose of this study was to confrm whether metabolic syndrome (MS) infuences the hearing outcome of S-SNHL in the Korean population.

Subjects and Method We prospectively investigated the clinical variables of 231 cases of S-SNHL from 2010 March to 2014 February. MS was defned according to the National Cholesterol Education Program Adult Treatment Panel III with Asian modifcations. We analyzed and compared the basic and clinical characteristics, the thresholds of pure tone audiometry (PTA), and the hearing outcomes of patients with MS (MS group) and without MS (NMS group).

Results There were no signifcant differences in the basic characteristics and initial hearing thresholds between the MS and NMS groups; on the other hand, there were signifcant differences in all of the clinical values of MS between the two groups. The average thresholds of final PTA for the MS and NMS groups were $52.9 \pm 30.9 \mathrm{~dB}$ and $40.5 \pm 27.2 \mathrm{~dB}$, respectively, with meaningful diversity $(p<0.01)$. According to Siegel's criteria, the recovery rate of the NMS group (95/159, 59.7\%) was signifcantly higher than those of the MS group (29/72, 40.3\%). The proportion of recovery within 5 days after starting the treatment was signifcantly higher of the NMS group (37/95, 39.0\%) than those of the MS group (4/29, 13.8\%) $(p<0.01)$.

Conclusion The hearing outcome of the NMS group was signifcantly better than those of the MS group.

Korean J Otorhinolaryngol-Head Neck Surg 2018;61(10):514-21

Key Words Diabetes mellitus · Dyslipidemia · Hypertension · Metabolic syndrome · Sudden sensorineural hearing loss.

\section{서 론}

돌발성 난청(sudden sensorineural hearing loss)은 뚜렷한 원인 없이 갑자기 발생하는 난청이 주 증상으로, 응급 처치가

This is an Open Access article distributed under the terms of the Creative Commons Attribution Non-Commercial License (https://creativecommons.org/licenses/by-nc/4.0) which permits unrestricted non-commercial use, distribution, and reproduction in any medium, provided the original work is properly cited.
필요한 이비인후과 질환 중 하나이며, 이환된 환자들에게는 매우 공포스러운 경험이다. 주로 중년층에서 일측으로 발생 하는 것으로 알려져 있고, 연간 유병률은 미국에서는 10 만 명 당 5 10명 정도로 보고된 바 있으며 ${ }^{1)}$ 한국에서도 10 만 명당 10 명 이상이 발병하는 것으로 알려져 있다. ${ }^{2}$ 일반적으로 3일 이내에 갑자기 발생하고 순음청력검사상에서 3 개의 연속된 주 파수에서 $30 \mathrm{~dB}$ 이상의 청력감소를 보일 때 진단할 수 있다. ${ }^{3)}$ 
이 질환의 가능성 있는 원인으로 바이러스 감염, 혈관 질환, 자가면역질환, 유전자 질환, 대사장애 등이 제시되고 있지만, 85 90\%의 환자에서는 주된 원인을 확실히 모르고 치료를 시작하게 되며, 다양한 검사를 통해 원인을 확인할 수 있는 경우는 전체의 $5 \%$ 미만에 불과한 것으로 알려져 있다. ${ }^{4)}$

대사증후군(metabolic syndrome, MS)은 복부 비만, 높은 혈압, 이상지질혈증(dyslipidemia), 높은 혈당 등이 동반되어 나타나는 대사 이상 상태로 ${ }^{5)}$ 대사증후군의 진단은 미국국립 보건원(National Institute of Health, NIH) 산하의 National Heart, Lung, and Blood Institute(NHLBI)에서 발표한 National Cholesterol Education Program-Adult Treatment Panel III(NCEP-ATP III)를 근간으로 하지만 아시아인을 위한 기준이 따로 제시되어 있다. 대사증후군은 혈관 내피 세포 기능장애 및 체내 염증 증가, 지방축적을 일으키며, 당 뇨, 고혈압(hypertension), 만성 콩팥병, 뇌졸중, 심근경색, 협 심증과 같은 대사 이상 및 심뇌혈관 질환의 위험인자로 작용 하여 전체 사망률 증가의 원인이 되는 것으로 알려져 있다. ${ }^{7)}$

최근 돌발성 난청의 병태생리에 대한 연구가 활발해지면서 심혈관 및 뇌혈관 질환의 위험인자와 돌발성 난청의 발병 및 예후에 대한 관련성이 조사 되고 있다. ${ }^{8}$ 당뇨병, 고혈압, 비만, 이상지질혈증 등은 미세혈관의 손상을 불러일으키면서 여러 합병증을 유발하게 되는 병리 상태이며, 이것은 돌발성 난청 의 원인으로 현재 널리 받아들여지는 와우의 허혈성 손상과 도 밀접하게 연관 지을 수 있다."

대사증후군도 미세혈관의 손상이라는 측면에서는 돌발성 난청의 치료 과정에 영향을 줄 수 있다고 생각되나, 돌발성 난청 환자 연구에서 대사증후군의 병발 여부에 대해서 고려 한 연구는 아직 많지 않다. 이에 본 연구에서는 대사증후군 의 여부가 돌발성 난청의 치료 결과에 어떤 차이가 있는지 확인해 보고자 하였다.

\section{대상 및 방법}

\section{대 상}

2010년 3월부터 2014년 2월까지 본원 이비인후과에 갑작스 런 난청으로 내원한 환자들 중 순음청력검사 및 어음청력검 사상 돌발성 난청 진단기준에 부합하여 입원치료를 시행받은 245 명의 환자들을 대상으로 전향적인 연구를 계획하였으며, 본 연구는 건양대학교병원 임상시험심사위원회(Institutional Review Board)의 승인을 받았다(IRB No. KYUH 2010-12019-002). 치료 시작 전 대사증후군을 진단할 수 있는 lipid panel 등의 혈액 검사, 혈압약이나 경구 혈당 강하제 및 인슐 린 사용여부 등의 과거력 문진, 그리고 치료 전 혈압 및 허리
둘레 측정을 위한 신체 계측을 시행하였으며, 입원 중 임피던 스(impedance) 청력검사, 이음향방사 검사(otoacoustic emission), 뇌간유발반응 검사(auditory brainstem response), 전정 기능 검사(vestibular function test) 및 측두부 MRI를 추가로 시행하였다. 전정신경종양(vestibular schwannoma) 등의 후미 로 병변, 뇌경색, 뇌출혈 등의 뇌병변, Meniere병, 다발성 경화 증(multiple sclerosis)이 확인되었거나, 두부외상, 소음 노출, 귀 수술 과거력, 재발성 돌발성 난청의 과거력이 있는 환자들 은 연구 대상에서 제외하였다. 총 231명의 환자가 조건에 부합 하였으며, 대사증후군이 병발되어 있는 환자군(MS group)과 병발되어 있지 않은 환자군(non-metabolic syndrome, NMS group)으로 나누어 치료 후 청력 호전의 정도를 비교하였다.

\section{치 료}

연구에 포함된 환자들은 5일간의 고농도 dexamethasone (Dexamethasone disodium phosphate ${ }^{\circledR}, 5 \mathrm{mg} / \mathrm{mL}$, Yuhan Corporation, Seoul, Korea) 정맥 주사 $(0.14 \mathrm{mg} / \mathrm{kg})$ 및 5일간 1 일 1회의 고실내 dexamethasone 주입술을 동시 시행하는 스 테로이드 복합치료를 근간으로 하였고, 이를 위해 5 일 이상 입 원가료 하였다. 입원기간 중에는 스테로이드 외에도 추가로 acyclovir(Vacrax ${ }^{\circledR}, 500$ mg, Aprogen Pharmaceuticals, Seongnam, Korea) 정맥주사 $(5 \mathrm{mg} / \mathrm{kg}$ tid) 및 ginkgo biloba (Tanamin $^{\circledR}, 35 \mathrm{mg} / 10 \mathrm{~mL}$, Yuyu Pharmaceuticals, Seoul, Korea) 정맥 주사 $(35 \mathrm{mg} \mathrm{qd})$ 도 하였고, 혈당 조절이 힘든 경 우에 한해 인슐린도 혈당에 맞추어 피하 주사(sliding scale) 하였다. 스테로이드 복합 치료 후에는 5일 간의 스테로이드 체감(tapering)을 반드시 시행하였다.

모든 환자군은 입원일에 순음청력검사, 어음청력검사를 시 행 받은 이후에 제5 상병일에 두 번째 청력검사를 시행하였 으며, 스테로이드 체감이 끝나는 치료 11일째 다시 외래를 방 문하여 세 번째 청력검사를 시행하였다. 이 시점에서 청력 회 복이 완전하지 않은 경우에는 2주간 4회에 걸쳐 추가적인 스 테로이드 고실내 주입술을 시행받았으며, 치료 25일째에 네 번째 청력검사를 시행하였다. 치료 45일째 및 90일째에 청력 검사를 다시 시행하게 되며, 90 일째 청력검사 역치를 치료 후 최종청력으로 규정하였다.

\section{대사증후군의 정의}

미국심장협회(American Heart Association, AHA) 및 세계 보건기구(World Health Organization, WHO)에서는 대사증 후군의 진단기준을 설정하여 적용하고 있지만 가장 보편적 인 기준은 NIH 산하의 NHLBI에서 발표한 NCEP-ATP III 를 따른 것이다.10) 이 판단 기준에 의하면 1) 고지혈증(hyper- 
lipidemia)은 중성지방(triglyceride)이 남녀 모두 $150 \mathrm{mg} / \mathrm{dL}$ 이상, 2) 고밀도지단백콜레스테롤(high density lipoproteincholesterol)의 감소는 여성의 경우 $50 \mathrm{mg} / \mathrm{dL}$ 미만, 남성은 40 $\mathrm{mg} / \mathrm{dL}$ 미만, 3) 고혈압은 남녀 모두 수축기 $130 \mathrm{~mm} \mathrm{Hg}$, 이완 기 $85 \mathrm{~mm} \mathrm{Hg}$ 이상이거나 고혈압 약제를 복용하는 경우, 4) 고혈당(hyperglycemia)은 남녀 모두 공복혈당이 $100 \mathrm{mg} / \mathrm{dL}$ 이상이거나 당뇨약제를 복용 및 사용중인 경우, 5) 허리둘레 (waist circumference)는 복부비만을 평가하는데 대륙, 인종 별로 다른 기준을 적용하며, 우리나라의 경우 남성은 $90 \mathrm{~cm}$ 이상, 여성은 $85 \mathrm{~cm}$ 이상을 기준으로 적용한다. ${ }^{6,10)}$ 이상의 5 가 지 기준 중에서 3 가지 이상에 해당하는 경우를 대사증후군 이라 진단하였다.

\section{청력의 평가}

청력의 평가는 내원 당일 및 제5 상병일, 치료 11 일째, 25 일 째, 45일째, 90 일째에 각각 순음청력검사 및 어음청력검사를 시행하였으며, 청력회복 정도의 판정은 최초 내원일과 치료 후 3 개월째의 청력검사 결과를 비교하였다. 최초 검사의 청력 역 치 평균에 따라 난청을 경도(mild, 26 40 dB), 중등도(moderate, 41 55 dB), 중등고도(moderate-severe, 56 70 dB), 고 도(severe, 71 90 dB) 그리고 농(profound, $91 \mathrm{~dB}$ 이상)으로 분류하였다. 최종 청력의 판정은 Siegel의 기준에 따라 최종 평균 역치가 $25 \mathrm{~dB}$ 보다 더 좋은 경우를 완전 회복(complete recovery), $15 \mathrm{~dB}$ 이상 호전되었으나 최종 평균 역치가 25 45

Table 1. The Siegel's criteria of hearing recovery

\begin{tabular}{lc}
\hline \multicolumn{1}{c}{ Type } & \multicolumn{1}{c}{ Hearing recovery } \\
\hline $\begin{array}{l}\text { Complete recovery } \\
\text { Partial recovery }\end{array}$ & $\begin{array}{c}\text { Final hearing level was better than } 25 \mathrm{~dB} \\
\text { More than } 15 \mathrm{~dB} \text { of gain, final hearing } \\
25-45 \mathrm{~dB}\end{array}$ \\
Slight improvement & $\begin{array}{c}\text { More than } 15 \mathrm{~dB} \text { of gain, final hearing } \\
\text { poorer than } 45 \mathrm{~dB}\end{array}$ \\
No improvement & $\begin{array}{c}\text { Less than } 15 \mathrm{~dB} \text { of gain or final hearing } \\
\text { poorer than } 75 \mathrm{~dB}\end{array}$ \\
\hline
\end{tabular}

$\mathrm{dB}$ 사이인 경우를 부분 회복(partial recovery), $15 \mathrm{~dB}$ 이상 호 전되었으나 최종 평균 역치가 $45 \mathrm{~dB}$ 보다 나쁜 경우를 약간 회 복(slight improvement), $15 \mathrm{~dB}$ 미만으로 회복되었으며 최종 평균 역치가 $75 \mathrm{~dB}$ 미만인 경우를 불변(no recovery)으로 판 정하였다(Table 1). ${ }^{11)}$ 또한 경도 이상의 청력회복이 이루어진 경우, 최종 청력에 평균 $5 \mathrm{~dB}$ 이하의 차이로 근접한 검사 결과 를 보이는 시기를 청력회복이 이루어진 시기로 결정하였다.

\section{통계 분석}

모든 자료는 전산 입력하였고, 통계분석은 PASW 18(IBM Company, Chicago, IL, USA)을 이용하였다. 연속 변수들은 평균표준편차의 형태로, 범주형 변수들은 빈도 및 비율의 형태로 표현하였다. 대사증후군이 병발된 돌발성 난청 환자 군과 병발되지 않은 돌발성 난청 환자군 사이의 기본 특징과 치료 후 청력, 호전 시기를 비교하였고, 독립 표본 $\mathrm{t}$ 검정, 카이 제곱검정을 시행하였다. 모든 분석에 있어서 $p$ 값이 0.05 미만 인 경우를 유의하다고 판단하였다.

\section{결 과}

\section{기본 특징 비교}

대사증후군이 병발된 돌발성 난청 환자군(MS group)은 72 명으로 총 231 명 환자의 $31.2 \%$ 를 차치하였다. 평균 나이 $53.0 \pm 13.3$ 세, 남녀 비가 31:41이었고, 신장은 $161.0 \pm 10.3 \mathrm{~cm}$, 체중은 $67.4 \pm 15.0 \mathrm{~kg}$ 이었다. 발병 후 초기 치료까지의 기간은 평균 4.2 \pm 3.6 일, 환측의 비율은 좌우가 30:42이었고, 어지러 움이 있는 경우는 26명(36.1\%), 이명이 있는 경우는 65명(90.3\%) 이었다. 대사증후군이 병발되지 않은 돌발성 난청 환자군 (NMS group)은 159명으로 평균 나이 51.2 \pm 16.0 세, 남녀 비 가 87:72이었고, 신장은 $162.9 \pm 9.5 \mathrm{~cm}$, 체중은 $64.3 \pm 12.2$ $\mathrm{kg}$ 이었다. 발병 후 초기 치료까지의 기간은 평균 $5.6 \pm 5.0$ 일, 환측의 비율은 좌우가 83:76이었고, 어지러움이 있는 경우는

Table 2. Base characteristics of MS group and NMS group in patients with sudden sensorineural hearing loss

\begin{tabular}{lccc}
\hline & MS group $(\mathrm{n}=72)$ & NMS group $(\mathrm{n}=159)$ & $\mathrm{p}$ value \\
\hline Age (year) & $51.0 \pm 13.3$ & $51.2 \pm 16.0$ & $0.25^{*}$ \\
Gender (M:F) & $31: 41$ & $87: 72$ & $0.10^{\dagger}$ \\
Height (cm) & $161.0 \pm 10.3$ & $162.9 \pm 9.5$ & $0.17^{*}$ \\
Weight (kg) & $67.4 \pm 15.0$ & $64.3 \pm 12.2$ & $0.10^{*}$ \\
Duration onset to hospital (day) & $4.2 \pm 3.6$ & $5.6 \pm 5.0$ & $0.42^{*}$ \\
Side (Rt:Lt) & $42: 30$ & $76: 83$ & $0.14^{\dagger}$ \\
Vertigo, $\mathrm{n}(\%)$ & $26(36.1)$ & $47(29.6)$ & $0.15^{\dagger}$ \\
Tinnitus, $\mathrm{n}(\%)$ & $65(90.3)$ & $139(87.4)$ & $0.53^{\dagger}$ \\
Healthy side PTA (dB) & $24.3 \pm 17.5$ & $20.0 \pm 19.2$ & $0.11^{*}$ \\
\hline
\end{tabular}

*independent sample t-test, ${ }^{\dagger}$ chi-square test. MS: metabolic syndrome, NMS: non-metabolic syndrome, PTA: pure tone average 
Table 3. Clinical values of MS group and NMS group in patients with sudden sensorineural hearing loss

\begin{tabular}{lccc}
\hline & MS group $(\mathrm{n}=72)$ & NMS group $(\mathrm{n}=159)$ & p value \\
\hline Body mass index $\left(\mathrm{kg} / \mathrm{m}^{2}\right)$ & $25.8 \pm 3.8$ & $24.2 \pm 3.7$ & $<0.01^{*}$ \\
Waist $(\mathrm{cm})$ & $90.9 \pm 9.9$ & $81.8 \pm 10.6$ & $<0.01^{*}$ \\
Hip $(\mathrm{cm})$ & $98.3 \pm 7.3$ & $94.3 \pm 9.0$ & $<0.01^{*}$ \\
Hypertension, $\mathrm{n}(\%)$ & $53(73.6)$ & $36(22.6)$ & $<0.01^{\dagger}$ \\
Diabetes mellitus, $\mathrm{n}(\%)$ & $40(55.6)$ & $13(8.2)$ & $<0.01^{\dagger}$ \\
Dyslipidemia, $\mathrm{n}(\%)$ & $23(31.9)$ & $19(10.1)$ & $<0.01^{\dagger}$ \\
Triglyceride $(\mathrm{mg} / \mathrm{dL})$ & $108.3 \pm 61.6$ & $69.8 \pm 40.4$ & $<0.01^{*}$ \\
HDL-C (mg/dL) & $46.3 \pm 10.6$ & $55.3 \pm 11.8$ & $<0.01^{*}$ \\
Fasting glucose (mg/dL) & $114.7 \pm 47.8$ & $<0.01^{*}$ \\
\hline
\end{tabular}

*independent sample t-test, ${ }^{\dagger} \mathrm{Chi}-$ square test. MS: metabolic syndrome, NMS: non-metabolic syndrome, HDL-C: high density lipoprotein-cholesterol

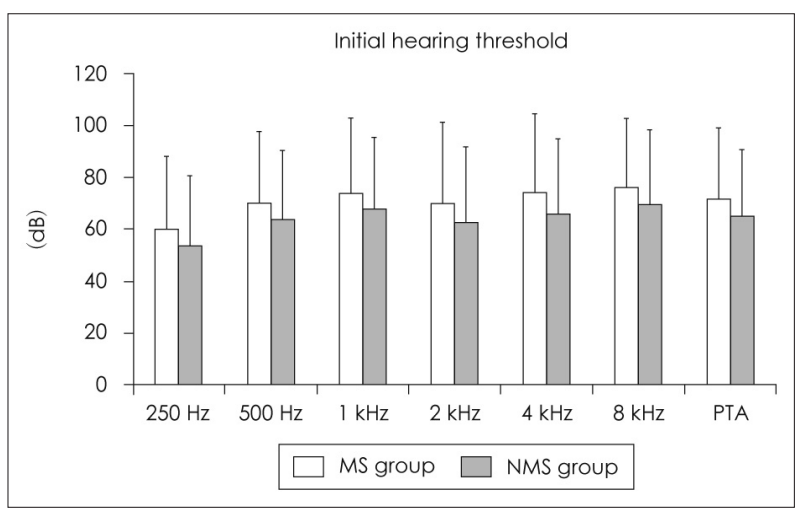

Fig. 1. Comparison of initial hearing threshold before treatment between MS group and NMS group. No significant differences in all frequencies between the two groups. MS: metabolic syndrome, NMS: non-metabolic syndrome, PTA: pure tone average.

47명(29.6\%), 이명이 있는 경우는 139명(87.4\%)이었다. 두 군 비교 시 남녀 비, 환측 방향, 어지러움과 이명의 동반 여부는 카이제곱검정을 시행하였으며 나이, 키, 몸무게, 발병 후 초 기 치료까지의 기간에 대해서는 독립 $\mathrm{t}$ 검정을 시행하였으나 두 군의 의미있는 차이는 없었다(Table 2).

\section{대사증후군 관련 인자 비교}

대사증후군이 병발된 돌발성 난청 환자군(MS group)에서 body mass index(BMI)는 $25.8 \pm 3.8 \mathrm{~kg} / \mathrm{m}^{2}$, 허리 및 엉덩이 둘레는 각각 $90.9 \pm 9.9 \mathrm{~cm}, 98.3 \pm 7.3 \mathrm{~cm}$ 이었다. 고혈압이 있는 경우는 53명(73.6\%), 당뇨가 있는 경우는 40명(55.6\%), 고지혈 증이 있는 경우는 23명(31.9\%)이었으며, 중성지방은 $108.3 \pm$ $61.6 \mathrm{mg} / \mathrm{dL}$, 고밀도지단백콜레스테롤은 $46.3 \pm 10.6 \mathrm{mg} / \mathrm{dL}$, 공복혈당은 $162.9 \pm 75.7 \mathrm{mg} / \mathrm{dL}$ 이었다. 대사증후군이 병발되

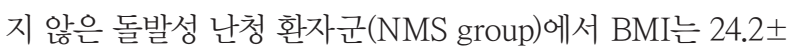
$3.7 \mathrm{~kg} / \mathrm{m}^{2}$, 허리 및 엉덩이 둘레는 각각 $81.8 \pm 10.6 \mathrm{~cm}, 94.3 \pm$ $9.0 \mathrm{~cm}$ 이었다. 고혈압이 있는 경우는 36 명 $(22.6 \%)$, 당뇨가 있 는 경우는 13 명(8.2\%), 고지혈증이 있는 경우는 16 명(10.1\%)
이었으며, 중성지방은 $69.8 \pm 40.4 \mathrm{mg} / \mathrm{dL}$, 고밀도지단백콜레 스테롤은 $55.3 \pm 11.8 \mathrm{mg} / \mathrm{dL}$, 공복혈당은 $114.7 \pm 47.8 \mathrm{mg} / \mathrm{dL}$ 이었다. 두 군 비교시 고혈압, 당뇨, 고지혈증의 여부는 카이 제곱검정을 시행하였으며 허리 및 엉덩이 둘레, 중성지방, 고 밀도지단백콜레스테롤, 공복혈당에 대해서는 독립 $\mathrm{t}$ 검정을 시행한 결과 모든 항목에 대해서 $p$ 값이 0.005 미만으로 두 군의 의미있는 차이가 확인되었다(Table 3).

\section{초기 청력 비교}

대사증후군이 병발된 돌발성 난청 환자군(MS group)의 경 우 환측의 각 주파수별 순음 청력 역치의 평균은 $0.25 \mathrm{kHz}$ 에서 $59.9 \pm 28.2 \mathrm{~dB}, 0.5 \mathrm{kHz}$ 에서 $70.0 \pm 27.8 \mathrm{~dB}, 1 \mathrm{kHz}$ 에서 $73.7 \pm 29.1 \mathrm{~dB}, 2 \mathrm{kHz}$ 에서 $69.8 \pm 31.8 \mathrm{~dB}, 4 \mathrm{kHz}$ 에서 $74.0 \pm$ $30.5 \mathrm{~dB}, 8 \mathrm{kHz}$ 에서 $75.9 \pm 26.6 \mathrm{~dB}$ 로, 6 분법상 평균은 $71.8 \pm$ $27.7 \mathrm{~dB}$ 이었으며, 건측의 평균 청력 역치는 $24.3 \pm 17.5 \mathrm{~dB}$ 이었 다(Fig. 1). 난청 정도는 경도 8명(11.1\%), 중등도 22명(30.6\%), 중등고도 15명(20.8\%), 고도 16 명(22.2\%), 농 11명(15.3\%)의 분 포를 나타내었다(Fig. 2). 대사증후군이 병발되지 않은 돌발 성 난청 환자군(NMS group)의 경우 환측의 각 주파수별 순 음 청력 역치의 평균은 $0.25 \mathrm{kHz}$ 에서 $53.5 \pm 27.5 \mathrm{~dB}, 0.5 \mathrm{kHz}$ 에서 $63.7 \pm 26.5 \mathrm{~dB}, 1 \mathrm{kHz}$ 에서 $67.7 \mathrm{~dB} \pm 27.9 \mathrm{~dB}, 2 \mathrm{kHz}$ 에서 $62.5 \pm 29.4 \mathrm{~dB}, 4 \mathrm{kHz}$ 에서 $65.9 \pm 28.8 \mathrm{~dB}, 8 \mathrm{kHz}$ 에서 $69.6 \pm$ $28.5 \mathrm{~dB}$ 로, 6 분법상 평균은 $65.0 \pm 25.7 \mathrm{~dB}$ 이었으며, 건측의 평균 청력 역치는 $20.0 \pm 19.2 \mathrm{~dB}$ 이었다. 난청 정도는 경도 30 명 (18.9\%), 중등도 45명(28.3\%), 중등고도 38명(23.9\%), 고도 28 명(17.6\%), 농 18명(11.3\%)의 분포를 나타내었다. 두 군 사 이의 각 주파수별 초기 청력 역치, 환측 및 건측의 평균 청력 역치에 대해서는 독립 $\mathrm{t}$ 검정을 시행하였으며, 두 군 사이의 난청 정도 비율에 대해서는 카이제곱검정을 시행하였다. 두 군 사이의 모든 주파수별 초기 청력 역치에는 통계적으로 의 미 있는 차이가 없었으며 $(p>0.1)$, 두 군 사이 환측과 건측의 


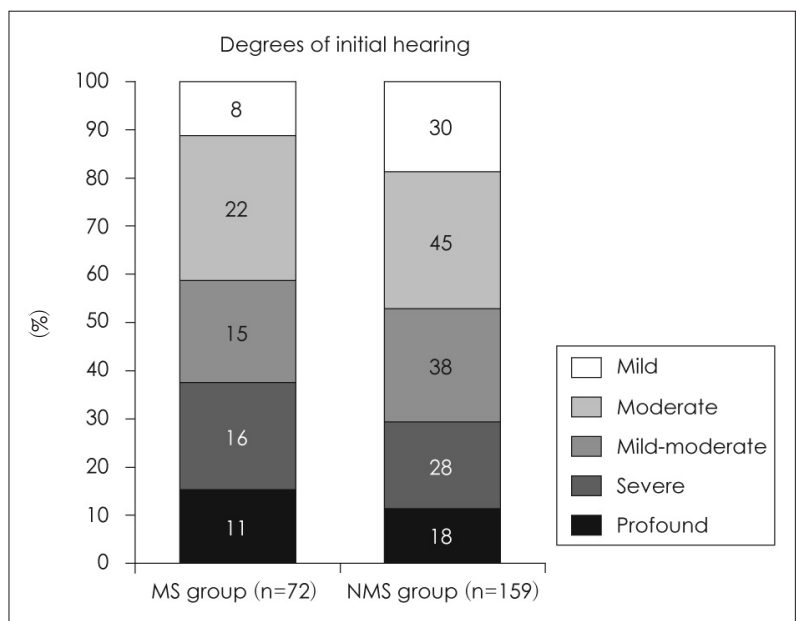

Fig. 2. Degrees of initial hearing threshold between MS group and NMS group. No significant difference in the distribution of hearing loss between two groups. MS: metabolic syndrome, NMS: non-metabolic syndrome.

청력 역치 평균도 마찬가지였다 $(p>0.1)$. 난청 정도의 비율도 두 군 사이에 유의한 차이는 없는 것으로 확인되었다 $(p>0.1)$.

\section{치료 후 청력 비교}

대사증후군이 병발된 돌발성 난청 환자군(MS group)의 경 우 환측의 각 주파수별 최종 순음 청력 역치의 평균은 0.25 $\mathrm{kHz}$ 에서 $42.8 \pm 31.2 \mathrm{~dB}, 0.5 \mathrm{kHz}$ 에서 $47.7 \pm 30.6 \mathrm{~dB}, 1 \mathrm{kHz}$ 에서 $51.0 \pm 32.4 \mathrm{~dB}, 2 \mathrm{kHz}$ 에서 $50.7 \pm 33.7 \mathrm{~dB}, 4 \mathrm{kHz}$ 에서 $62.3 \pm 32.3 \mathrm{~dB}, 8 \mathrm{kHz}$ 에서 $68.7 \pm 29.1 \mathrm{~dB}$ 로, 6 분법상 평균은 $52.9 \pm 30.9 \mathrm{~dB}$ 이었다. Siegel 기준에 따라 회복의 정도를 나누 면 완전 회복 19명(26.4\%), 부분 회복 10명(13.9\%), 약간 회복 16 명(22.2\%), 불변 27명(37.5\%)의 분포를 보였다. 대사증후군 이 병발되지 않은 돌발성 난청 환자군(NMS group)의 경우 환 측의 각 주파수별 최종 순음 청력 역치의 평균은 $0.25 \mathrm{kHz}$ 에서 $29.8 \pm 27.9 \mathrm{~dB}, 0.5 \mathrm{kHz}$ 에서 $34.7 \pm 28.5 \mathrm{~dB}, 1 \mathrm{kHz}$ 에서 $38.7 \pm 29.6 \mathrm{~dB}, 2 \mathrm{kHz}$ 에서 $39.0 \pm 29.7 \mathrm{~dB}, 4 \mathrm{kHz}$ 에서 $49.6 \pm$ $30.1 \mathrm{~dB}, 8 \mathrm{kHz}$ 에서 $58.4 \pm 32.0 \mathrm{~dB}$ 로, 6 분법상 평균은 $40.5 \pm$ $27.2 \mathrm{~dB}$ 이었다. Siegel 기준에 따라 회복의 정도를 나누면 완 전 회복 62명(39.0\%), 부분 회복 33명(20.7\%), 약간 회복 27명 (17.0\%), 불변 37명(23.3\%)의 분포를 보였다. 두 군 사이의 각 주파수별 최종 청력 역치, 평균 최종 청력 역치에 대해서는 독립 t 검정을 시행하였으며, 두 군 사이 회복 정도의 비율에 대해서는 카이제곱검정을 시행하였다. 최종 청력은 대사증후 군이 병발되지 않은 군(NMS group)이 모든 주파수에서 병발 된 군(MS group)보다 더 좋았으며 $(p<0.05)$, 최종 청력의 평균 도 마찬가지였다( $p=0.02)$ (Fig. 3).

Siegel의 기준상 부분 호전 및 완전 호전된 환자들을 묶어 호전군(recovery group)으로 잡는다면, 대사증후군이 병발된

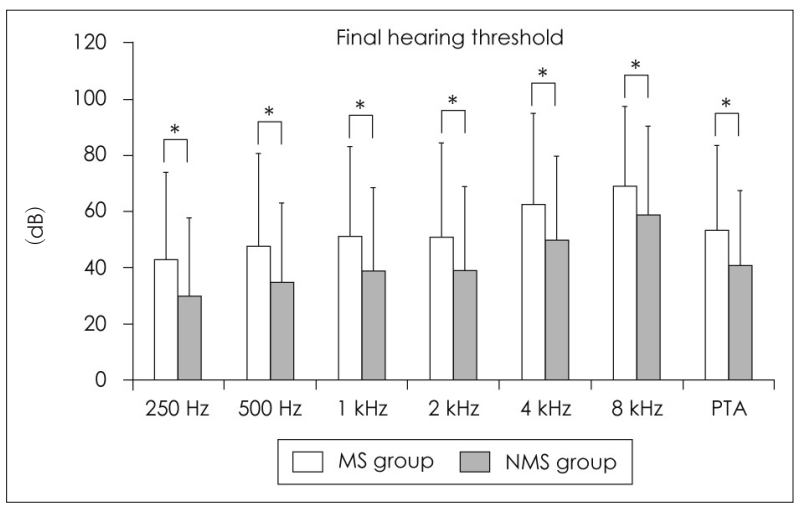

Fig. 3. Comparison of final hearing thresholds at 3 months after starting treatment between MS group and NMS group. The hearing outcome of NMS group was better than those of MS group in all frequencies and pure tone average. * significant different $(p<0.05)$ in independent t-test. MS: metabolic syndrome, NMS: non-metabolic syndrome, PTA: pure tone average.

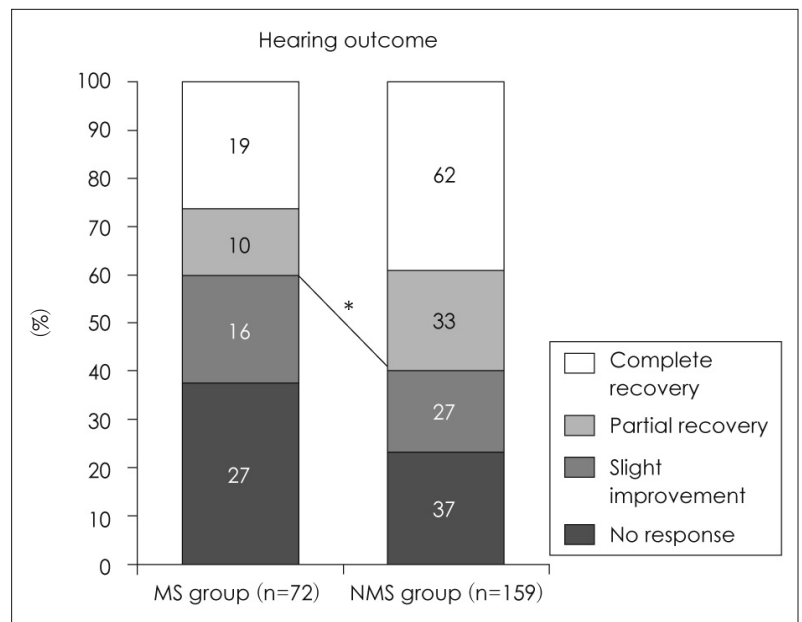

Fig. 4. Comparison of hearing outcome between two groups according to Siegel's criteria. The recovery rates, included 'complete recovery' and 'partial recovery,' in NMS group was signifcantly higher than those of MS group. *significant difference $(p<0.01)$ in chi-square test. MS: metabolic syndrome, NMS: non-metabolic syndrome.

돌발성 난청 환자군(MS group)에서는 호전군이 29명(40.3\%), 대사증후군이 병발되지 않은 돌발성 난청 환자군(NMS group) 에서는 95 명 $(59.7 \%)$ 으로 확인되어 대사증후군이 동반되지 않은 군에서 호전군이 더 많은 비율로 나타났다 $(p<0.01)$ (Fig. 4). 호전군의 회복 시기를 두 군에서 비교해보면, 대사증후군 이 병발된 돌발성 난청 환자군(MS group)에서는 5일째 4명 (13.8\%), 11일째 22명(75.9\%), 25일째 3명(10.3\%)이었으나, 대 사증후군이 병발되지 않은 돌발성 난청 환자군(NMS group) 에서는 5일째 37명(39.0\%), 11일째 46명(48.4\%), 25일째 12명 (12.6\%)이었다. 호전군에 속하는 환자는 25일 이내에는 모두 회복 되었으며, 대사증후군이 병발되지 않은 돌발성 난청 환 자군(NMS group)이 대사증후군이 병발된 환자군(MS group) 


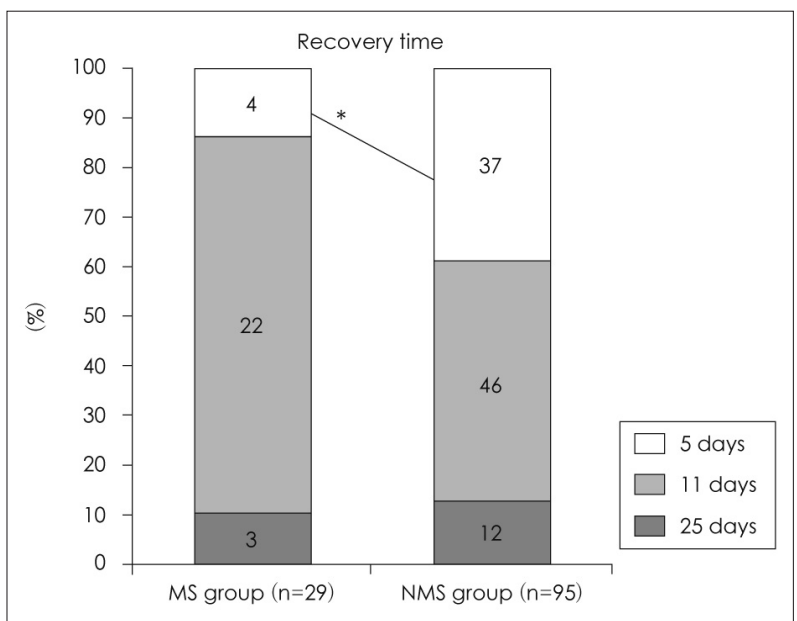

Fig. 5. Comparison of the periods of time from starting treatment to recovery between MS group and NMS group. The proportion of repaired patients within 5 days after starting the treatment was significantly higher in NMS group (39.0\%) than those in MS group $(13.8 \%)$. *significant difference in chi-square test $(p<0.01)$. MS: metabolic syndrome, NMS: non-metabolic syndrome.

보다 5 일 이내에 회복되는 경우가 유의하게 많았다 $(p<0.01$, 카이제곱검정)(Fig. 5).

\section{고 찰}

돌발성 난청은 갑작스러운 청각 소실을 일으키는 응급 귀 질 환으로 병태생리, 효과적인 치료법, 예후 인자 등에 대하여 여 러 가지 이론이 제기되고 있지만 아직은 이렇다 할 의견 일치 가 이루어지지 않은 상태이며, 많은 관련 연구들이 진행 중인 질환이다. 돌발성 난청의 원인으로는 바이러스 감염, 자가면 역반응, 외상, 혈류 장애, 대사 질환 등의 가능성이 제시되었 으나 확실한 병인은 아직 밝혀지지 않았다. 와우의 혈관 분포 를 살펴보면, 뇌기저동맥(basilar artery)에서 기시하는 전하소 동맥(anterior inferior cerebellar artery)의 한 가지인 미로동 맥(labyrinthine artery)에서만 단일 혈액 공급을 받는 말단 기관이며, 측부 순환이 풍부하지 않아 일시적인 허혈상태에 서도 쉽게 와우의 기능에 영향을 미칠 수 있는 구조적 문제 로 와우로 가는 혈류 장애에 의해 돌발성 난청이 발생할 수 있다는 가능성이 가장 널리 인용되고 있다. ${ }^{12}$ 혈류장애는 비 단 병태 생리학적인 문제만은 아닐 것으로 생각되는데 이상 지질혈증, 당뇨, 고혈압, 흡연력과 같은 심혈관계 위험 인자를 가진 환자들이 돌발성 난청 발병 시 좋지 않은 예후를 보인 다는 보고들도 다수 있기 때문이다. ${ }^{13-15)}$

대사증후군 또한 발생기전이 아직 명확하게 밝혀지진 않았 으나, 종양괴사인자- $\alpha$ (tumor necrosis factor $-\alpha, \mathrm{TNF}-\alpha)$ 나 interleukin-6와 같은 염증전구물질이 대사증후군 환자의
혈중에서 증가되어 있으며, 기전에 중요한 역할을 할 것이라 는 의견이 제시된 바 있다. ${ }^{16}$ 염증성 사이토카인 등이 혈관 내 에서 염증 반응을 촉진시켜 죽상동맥경화증의 발생을 용이 하게 하고, $\mathrm{TNF}-\alpha$ 등은 $\mathrm{H}_{2} \mathrm{O}_{2}$ 생성을 통해 인슐린 저항성을 일으키고 수축기 혈압 증가를 일으킬 수 있다는 실험 연구들 도 이러한 가설을 뒷받침 한다. ${ }^{1718)}$ 따라서 아직 대사증후군 이 돌발성 난청의 발생에 직접적으로 기여하는 바는 입증되 어 있지 않지만, 대사증후군이 혈관 속 혈액의 이상 혈압, 비 정상적인 혈당 분포, 이상 지질로 인한 점도의 이상, 염증 반응 증가 등을 포함하는 증후군성 질환이기 때문에 와우의 미세 혈류와 염증에도 영향을 미칠 수 있을 것으로 보인다. 대사 증후군이 동반된 돌발성 난청 환자들이 적절한 치료에도 불 구하고 비대사증후군 돌발성 난청 환자들보다 치료 반응이 상대적으로 떨어지는 주된 이유도 아마 이러한 영향 때문이 라고 생각한다.

대사증후군의 유병률에 대한 국내 보고는 1998년 국민건 강영양조사에 따른 연구에서 남성 $19.9 \%$, 여성 $23.7 \%$ 로 보고 된 바 있으며, ${ }^{19)}$ 2009 2010년 단면적 분석을 통해 $18.86 \%$ 라 고도 보고되었다. ${ }^{20)}$ 본 연구에서의 돌발성 난청 환자들은 $31.2 \%$ 의 유병률을 보여 과거 발표된 일반인의 유병률보다는 높다고 생각할 수 있겠지만, 2001년, 2005년, 2007년 이어진 국민건강영양조사에 따른 연구에서 한국인의 대사증후군 유 병률이 각각 $29.2 \%, 30.3 \%, 31.3 \%$ 로 점점 증가하고 있으므 로 $^{21)}$ 돌발성 난청 환자들에게 대사 증후군의 유병률이 높다 고 보기에는 아직 정황상 어렵다고 생각한다. 한 연구에서는 최근 대사증후군의 유병률이 증가한 것은 그동안 서양국가 와 차이가 있었던 이상지질혈증의 유병률과 복부비만의 유 병률이 증가한 것이 원인이라고 지적하였으며, 국가 차원에 서의 해결책을 촉구하기도 하였다. ${ }^{22)}$

현재까지 단편적으로 고혈압이나 당뇨, 고지혈증이 돌발성 난청의 청력 결과에 미치는 영향에 대해서는 보고된 바가 있 으나, ${ }^{2,9,23)}$ 대사증후군과 돌발성 난청에 대한 연구는 거의 이 루어지지 않은 실정이다. 단면적으로 보기에 대사증후군에 는 당뇨, 고혈압, 고지혈증에 대한 진단기준이 포함되어 있어 돌발성 난청의 결과에 영향을 주었던 각각의 요소에 대한 기 존 연구들과 이번 대사증후군 연구의 차별성이 크지 않아 보 일 수도 있다. 하지만 실제 대사증후군의 정의에는 고혈압 전 단계 및 당뇨 전단계 수준도 진단 기준에 포함이 되어, 고혈 압, 당뇨로 진단되지 않았던 환자들이라 할지라도 복부 비만 이나 고지혈증과 동반이 될 경우 대사증후군이라는 새로운 질환으로 진단이 될 수 있다. 그리고 당뇨, 고혈압, 고지혈증, 비만 등의 대사성 질환들의 병태생리가 다양한 기전들로 연 관되어 있어 나누어 생각하기보다는 대사증후군이라는 형태 
로 대부분의 질병 관련 연구가 이루어지는 흐름에 있다는 점 이 이번 대사증후군 관련 연구를 좀 더 주목해야 하는 이유 로 충분하다고 볼 수 있겠다. 현재까지는 Chien 등 ${ }^{24)}$ 이 유일 하게 대사증후군의 유병이 돌발성 난청의 발생을 3.54배 증 가시킨다고 보고한 바 있으나, 대사증후군의 어떤 요인도 돌 발성 난청의 청력 결과에 영향을 주지는 못하는 것으로 기술 하여 본 연구의 결과와는 상반되는 부분이 있었다.

Siegel의 기준에 따라 최종 청력이 완전 회복이거나 부분 회복으로 판단되는 환자들을 반응군으로 하고, 약간 회복이 거나 불변인 경우를 무반응군으로 두어 청력 결과를 판단하 는 시도는 많은 돌발성 난청 연구에서 시행되었던 방법이다. 이번 연구에서 약간 회복에 속하는 환자들까지도 반응군으 로 해석하여 비교를 하더라도, 대사 증후군이 병발되지 않은 돌발성 난청 환자군(NMS group)이 병발된 군(MS group)보 다 반응군의 비율이 높았다 $(p<0.01)$. 회복의 시점을 비교하 는 부분에서는 정확한 날짜의 비교가 아니라는 어려움이 있 었지만 환자들이 매일 외래를 방문하여 청력검사를 하기는 어려운 부분이므로 치료 5일째, 11 일째, 25일째 외래 방문 일 자로 제한하여 대략적으로 비교 할 수밖에 없었지만, 그럼에 도 불구하고 회복 시점과 관련된 부분에도 대사증후군 동반 여부에 따라 차이가 있었다.

이번 연구의 결과는 와우 관류 장애를 일으킬 수 있는 대 사증후군이 돌발성 난청의 회복에 영향을 미칠 수 있을 것이 라는 가설에는 부합하였으나 대상이 한국인에게만 집중되어 있고 연구 분석이 단면적인 비교에 지나지 않은 단점이 있었 다. 추후 대사증후군이 병반된 돌발성 난청 환자가 더 모집 된다면 회귀분석을 통해 청력 결과에 영향을 줄 수 있는 다 른 요인을 억제한 상태에서 대사증후군이 돌발성 난청의 청 력 회복에 영향을 주는지, 혹은 진단기준 중의 특정 부분이 돌발성 난청 회복에 영향을 줄 수 있는 지도 확인해 볼 수 있 겠다. 또한 동일 조건의 정상 청력 대조군을 모집하여 환자대조군 연구를 통해 한국인에게서 대사 증후군이 돌발성 난 청의 발생에 얼마나 기여하는지도 확인할 수 있을 것이라 생 각한다.

이번 연구의 의의는 돌발성 난청 진단 시 대사증후군 여부 를 미리 확인하여 치료 시 환자의 예후 상담에도 이용할 수 있으며, 돌발성 난청뿐만 아니라 심장 및 뇌혈관 질환의 선별 검사 여부를 결정하는 계기로 작용하리라 생각한다. 또한 스 테로이드 치료를 통한 와우의 기능 회복 도모 외에도 와우 관류를 억제시키는 요인들을 동시에 교정하는 것이 앞으로 의 돌발성 난청 치료의 새로운 방향이 되어야 할 것으로 생 각한다.

\section{Acknowledgments}

This work was supported by Konyang University Myunggok Research Fund of 2017.

\section{REFERENCES}

1) Rambold H, Boenki J, Stritzke G, Wisst F, Neppert B, Helmchen C. Differential vestibular dysfunction in sudden unilateral hearing loss. Neurology 2005;64(1):148-51.

2) Nam JS, Jeong SW, Han SJ, Chang JH, Choi HS. Idiopathic sudden sensorineural hearing loss is correlated with an increased risk of stroke: an 11-year nationwide population-based study. Korean J Otorhinolaryngol-Head Neck Surg 2016;59(5):353-60.

3) Schreiber BE, Agrup C, Haskard DO, Luxon LM. Sudden sensorineural hearing loss. Lancet 2010;375(9721):1203-11.

4) Hughes GB, Freedman MA, Haberkamp TJ, Guay ME. Sudden sensorineural hearing loss. Otolaryngol Clin North Am 1996;29(3): 393-405.

5) Reaven GM. Banting lecture 1988. Role of insulin resistance in human disease. Diabetes 1988;37(12):1595-607.

6) Choi SH, Kim DJ, Lee KE, Kim YM, Song YD, Kim HD, et al. Cutoff value of waist circumference for metabolic syndrome patietns in Korean adult population. J Korean Soc Study Obes 2004;13(1): 53-60.

7) Isomaa B, Almgren P, Tuomi T, Forsén B, Lahti K, Nissén M, et al. Cardiovascular morbidity and mortality associated with the metabolic syndrome. Diabetes Care 2001;24(4):683-9.

8) Lin C, Lin SW, Lin YS, Weng SF, Lee TM. Sudden sensorineural hearing loss is correlated with an increased risk of acute myocardial infarction: a population-based cohort study. Laryngoscope 2013;123 (9):2254-8

9) Mosnier I, Stepanian A, Baron G, Bodenez C, Robier A, Meyer B, et al. Cardiovascular and thromboembolic risk factors in idiopathic sudden sensorineural hearing loss: a case-control study. Audiol Neurootol 2011;16(1):55-66.

10) Alberti KG, Eckel RH, Grundy SM, Zimmet PZ, Cleeman JI, Donato KA, et al. Harmonizing the metabolic syndrome: a joint interim statement of the International Diabetes Federation Task Force on Epidemiology and Prevention; National Heart, Lung, and Blood Institute; American Heart Association; World Heart Federation; International Atherosclerosis Society; and International Association for the Study of Obesity. Circulation 2009;120(16):1640-5.

11) Siegel LG. The treatment of idiopathic sudden sensorineural hearing loss. Otolaryngol Clin North Am 1975;8(2):467-73.

12) Sidman JD, Prazma J, Pulver SH, Pillsbury HC 3rd. Cochlea and heart as end-organs in small vessel disease. Ann Otol Rhinol Laryngol 1988;97(1):9-13.

13) Aimoni C, Bianchini C, Borin M, Ciorba A, Fellin R, Martini A, et al. Diabetes, cardiovascular risk factors and idiopathic sudden sensorineural hearing loss: a case-control study. Audiol Neurootol 2010;15(2):111-5.

14) Kim C, Sohn JH, Jang MU, Hong SK, Lee JS, Kim HJ, et al. Ischemia as a potential etiologic factor in idiopathic unilateral sudden sensorineural hearing loss: analysis of posterior circulation arteries. Hear Res 2016;331:144-51.

15) Passamonti SM, Di Berardino F, Bucciarelli P, Berto V, Artoni A, Gianniello F, et al. Risk factors for idiopathic sudden sensorineural hearing loss and their association with clinical outcome. Thromb Res 2015;135(3):508-12.

16) Yudkin JS, Kumari M, Humphries SE, Mohamed-Ali V. Infammation, obesity, stress and coronary heart disease: is interleukin-6 the link? Atherosclerosis 2000;148(2):209-14.

17) Hansen LL, Ikeda Y, Olsen GS, Busch AK, Mosthaf L. Insulin signaling is inhibited by micromolar concentrations of $\mathrm{H}(2) \mathrm{O}(2)$. 
Evidence for a role of $\mathrm{H}(2) \mathrm{O}(2)$ in tumor necrosis factor alpha-mediated insulin resistance. J Biol Chem 1999;274(35):25078-84.

18) Zinman B, Hanley AJ, Harris SB, Kwan J, Fantus IG. Circulating tumor necrosis factor-alpha concentrations in a native Canadian population with high rates of type 2 diabetes mellitus. J Clin Endocrinol Metab 1999;84(1):272-8

19) Park HS, Oh SW, Kang JH, Park YW, Choi JM, Kim YS, et al. Prevalence and associated factors with metabolic syndrome in South Korea: from the Korean National Health and Nutrition Examination Survey, 1998. Korean J Obes 2003;12(1):1-14.

20) Kim SH, Choi HS, Ji SH, Park YM, Cho KH. The relationship of the prevalence metabolic syndrome and the difference of life style in Korean adult. Korean J Fam Pract 2015;5(Suppl 3):S500-9.
21) Oh JD, Lee S, Lee JG, Kim YJ, Kim YJ, Cho BM. Health behavior and metabolic syndrome. Korean J Fam Med 2009;30(2):120-8.

22) Lim S, Shin H, Song JH, Kwak SH, Kang SM, Yoon JW, et al. Increasing prevalence of metabolic syndrome in Korea: the Korean National Health and Nutrition Examination Survey for 1998-2007. Diabetes Care 2011;34(6):1323-8.

23) Lin CF, Lee KJ, Yu SS, Lin YS. Effect of comorbid diabetes and hypercholesterolemia on the prognosis of idiopathic sudden sensorineural hearing loss. Laryngoscope 2016;126(1):142-9.

24) Chien CY, Tai SY, Wang LF, Hsi E, Chang NC, Wu MT, et al. Metabolic syndrome increases the risk of sudden sensorineural hearing loss in Taiwan: a case-control study. Otolaryngol Head Neck Surg 2015; 153(1):105-11. 